could not long be tolerated in the aircraft. Concentrations of this order are common at 15 to $18 \mathrm{~km}$, and may occasionally be ten to fifty times as great; at $21 \mathrm{~km} \mathrm{a}$ value 100 times the danger level may be encountered. Fortunately, ozone is easily removed by filters, which will be fitted to the aircraft.

Rain and hail are less easy to deal with. Hailstones, the report says, constitute one of the greatest dangers to supersonic flight. For this reason, it will be vital to avoid penetrating cumulo-nimbus cloud at cruising speed, and detection by airborne radar will be provided. But a supersonic aircraft takes 100 miles to change course by $90^{\circ}$, so the equipment will have to be reliable, and carefully watched.

\section{Industrial Oceanography}

A nUmber of French industrial companies have formed a scientific and technical association for the exploration of the oceans, ASTEO. The association had its origin in a project of the development council of Aquitaine to establish a regional bureau of marine engineering. It was soon realized, however, that the task of co-ordinating the large number of industries and scientific techniques would require a national organization. The members of the new association, therefore, are companies from all over France, but the association's headquarters will be in Bordeaux. Naturally enough, several shipyards belong to the association, and two of the biggest French shipping companies, Messageries Maritimes and the Compagnie Générale Transatlantique, are also among the founder members. But there are a number of firms on this list with relatively few nautical associations: Hispano and SCNEMA, Nord-Aviation, Dassault and SudAviation, the Compagne Générale d'Electricité, and SEREB (Société pour l'Etude et la Réalisation des Engins Ballistics), whose director-general, M. Charles Cristofini, will be the first president of the association.

Among the first aims of the association will be to review the possibilities for French industry in oceanography. It is also hoped to establish an information centre which would use the computers of the SEREB at Bordeaux or the Compagnie Générale d'Electricité at Marcoussis. M. Cristofini has taken care to emphasize that the association is in no way a competitor of the National Centre for the Exploration of the Oceans. Rather, the new association, some of whose members are also members of CNEXO, will complement the older organization.

In Britain the participation of diverse industries in oceanography is rather less formally ordered. This may be partly because certain large British companies active in oceanographical research, such as Hawker Siddeley and Vickers, have many subsidiaries or associates specializing in the techniques involved in this kind of work. Co-operation is within the company rather than between companies. But it is interesting to note that the British Aircraft Corporation has been working with Imperial Colloge, and with the assistance of the Bristol shipyard of Charles Hill, and Normalair Ltd, on the development of an underwater house (Project Kraken). The Kraken house would be situated a hundred feet below the surface, and would allow divers to work at depth without having to undergo decompression. The Guided Weapons Division of $\mathrm{BAC}$ will be investigating the type of structure needed for the Kraken house, and working on the features necessary to support life. This is the first submarine excursion of this kind by BAC, though the Guided Weapons Division played a small part in the British Polaris programme.

The general objectives for Kraken-named after Tennyson's sea-monster-have been laid down by the Imperial College team led by Brian Ray. These are for a house capable of providing life support to a 4-man research team living at depths of 80-100 ft. for 2-3 weeks or more. There would also be an ample margin for visitors on shorter missions. This range lies just within the working range of the atmospheric gases. Most of the work on saturation dives (in France and the United States) has concentrated on greater depths and on oxyhelium saturation. Remarkably little is known about the effects of prolonged saturation with air under pressure. Thus a prime objective of the experiment is to gather physiological data on air saturation diving. The chosen depth range is practical in a number of ways. The cheap gas and modest depth will keep down mining costs. Much of Britain's continental shelf is within range for 100 foot diving platforms.

By living at depth much more work can be done than from surface dives, each one of which must be followed by lengthy decompression. Kraken's promoters believe that the practical value of the house will lie in the commercial fields of prospecting, of surveying and for research in support of fish farming.

The quarters that BAC has designed round these objectives are a structure rather like a railway coach divided in two internally. The all-purpose living area will be 14 foot long and permanently heated by a system of hot water circulating in pipes. The 10 foot work area will not be heated. There is no need for a pressure vessel hull since pressure inside and outside Kraken will be at equilibrium (varying a little with the rise and fall of the tide). The house will be permanently open to the sea through a hole in the bottom. Gas and power will be piped from the surface. The only thing still lacking is the money to build the operational house for next summer.

\section{More Social Science}

Total research and development expenditure in the United States during 1968 will reach $\$ 26,500 \mathrm{~m}-$ an increase of over $\$ 700 \mathrm{~m}$ or of 3.3 per cent compared with the estimated expenditure for 1967. This is the New Year message from the Battelle Memorial Institute, whose last year's prediction for the 1967 expenditure was in fact 8 per cent below the current estimate.

The Federal Government is the largest contributor to research and development expenditure, and during 1968 is expected to provide $\$ 17,200 \mathrm{~m}$, an increase of $2 \cdot 2$ per cent on its support last year. Industry will spend $\$ 8,300 \mathrm{~m}$, an increase of 4.8 per cent, and the colleges and universities about $\$ 865$ million, which at 8.8 per cent is the largest proportionate increase on last year's figures. The remainder of 1968 spending is made up by the $\$ 265$ million which will be provided by other non-profitmaking institutions. The Battelle Institute points out that although the Federal Government is the major source of research funds, accounting for 65 per cent of the total, 69 per cent of all research 
is in fact carried out in industry. These figures take account of the reduction in Federal research funds voted by Congress last month (Nature, 216, 1155; 1967).

Analysis of 1968 expenditure shows a relative shift to the social sciences in the distribution of Federal research funds. For the first time since figures became available, the increase in Federal spending in this sector will be greater than the increase in the physical sciences. Rescarch into social problems is a dominant factor in the programmes administered by the Department of Health, Education and Welfare (HEW), the Department of Housing and Urban Development (HUD), the Department of Labor and the Office of Economic Opportunity (OEO). The 1968 fiscal year budgets for these departments are 220 per cent higher than those for comparable programmes in 1961. In contrast the spending on research and development by the Department of Defense, NASA and AEC has increased by only 73 per cent during this period, most of which is a result of the substantial rise in space expenditure. Nevertheless, these three agencies will receive 86 per cent of Federal research funds in 1968, as distinet from their 91 per cent share in 1961 .

In the decade 1955-65, research and development expenditure grew at an annual rate of 14 per cent, against an annual growth rate of 5.5 per cent in gross national product. The Battelle Institute feels that this runaway rate of growth has now been contained and will remain so for the foreseeable future. Henceforth research and development is likely to grow at about the same rate as the GNP. Budget administrators in other countries who have watched with alarm the importunate demands of science research will take cheer from the modus vivendi now apparently reached in the United States. Scientists may feel differently.

\section{Teaching Aids in Sussex}

A GRANT of $£ 10,000$ has been awarded by the Depart. ment of Education and Science to the Centre for Academic Services at the University of Sussex to assist a co-operative project for the development and application of educational technology at all levels of education in the region. The centre at Sussex is one of the ten which were selected by the University Grants Committee to develop audio-visual aids in education. It was founded in February 1966 with the help of a grant from the Rank Organization.

This particular study will be carried out in associa. tion with the Nuffield Resources for Learning Project and the five local education authorities of East Sussex, West Sussex, Brighton, Eastbourne and Hastings. The objective is to analyse the existing audio-visual resources in schools and to estimate the potential for educational technology in the area. Regional co-operation in developing new methods and equipment will be considered and the costs and possible effects of such developments will be analysed. The proposals for joint activity include programmed learning, radio, closed circuit and broadcast television, language laboratories and film and projection systems.

A policy committee has been set up by the university to advise on the project and includes the five chief education officers of Sussex, Mr R. H. Adams (divisional inspector of schools for the south-east of
England), Mr Tim McMullen (co-ordinating director of the Nuffield Resources for Learning Project), Professor G. Allen (sub-dean of the University School of Educational Studies), and $\mathrm{Mr}$ Norman Mackenzie and $\mathrm{Mr}$ Hywel C. Jones (director and deputy director of the Centre for Academic Services); the university will act as co-ordinator for the scheme. The project was started on November 1, 1967, and is expected to last for two or three years.

What is interesting about the scheme is that it involves the getting together of five local education authorities with the university, to their mutual advantage. According to Mr Norman Mackenzie, although the operation is a modest one it will at least show how advantageous such co-operation can be.

\section{Training Computer Users}

THe Government and industry are well aware of the need for trained computer manpower and of the shortage of suitable training courses for such personnel. To help satisfy this demand, the British Computer Society is introducing professional qualifications this year. And training courses for computer users, particularly those on the professional and managerial side, are also important. It is therefore welcome that new and extended computer courses are being made available, from the end of January, to people in just this group by Rolls-Royce Ltd.

Rolls-Royce has for many years organized a wide range of courses of various levels in computing and data processing for its own staff. The Ministry of Technology seems to have suggested that the firm's courses should be extended to people from other firms. The suggestion was accepted and the courses now offered have been designed to make them acceptable to people from a broad range of other organizations.

Five-day residential courses in computer systems in management design, research and development will be held in Nottingham at a cost of 150 guineas each (one guinea $=£ 1 \cdot 05$ ). One-day appreciation courses for executives for $\mathbf{2 5}$ guineas will be held in Manchester and London. Four-week courses in systems analysis and design will be held in Largs, Stratford upon Avon, Derby and Droitwich. In addition there will be three short courses for directors of firms with a turnover of $£ 50$ million and above. The value of these new courses may lie in the wide experience of Rolls-Royce in specific applications of computers.

\section{New Look Laboratories}

THE 39th Building Bulletin of the Department of Education and Science (HMSO, 13s. 6d.) deals with the design of a science block for a large boys' grammar school. The block was designed for the Oxford School - a new school formed by the merger of the oldestablished City of Oxford High School and the prewar Southfields School. Four architects and a quantity surveyor of the Development Group of the Architects and Building Branch at the ministry worked on the project in collaboration with the Oxford local authority. Two consulting firms were called in to advise on heating and electrical work, and the school was built in just over a year and a half.

The importance of science in the curriculum seems to have been fully appreciated from the beginning, 